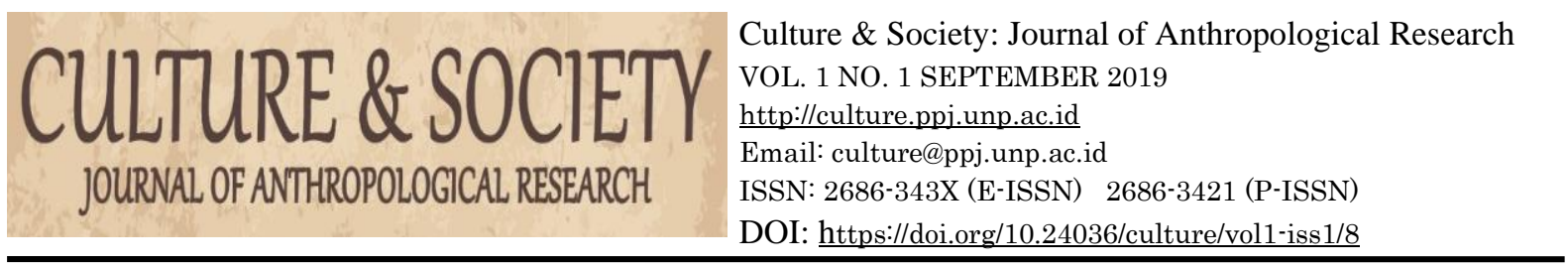

\title{
Mitigasi Bencana Banjir Pada Masyarakat di Kelurahan Dadok Tunggul Hitam Kecamatan Koto Tangah Kota Padang
}

\section{Putri Novela Sari ${ }^{1}$, Erianjoni Erianjoni ${ }^{2}$}

${ }^{1,2}$ Universitas Negeri Padang

Email: putrinovelasari18@gmail.com, erianjonisosiologi@gmail.com

\begin{abstract}
Abstrak
Penelitian ini dilatarbelakangi untuk mengetahui upaya Mitigasi Bencana Banjir Pada Masyarakat di Kelurahan Dadok Tunggul Hitam Kecamatan Koto Tangah Kota Padang. Penelitian ini menggunakan pendekatan kualitatif, teknik pengumpulan data dengan wawancara dan observasi. Penelitian ini dianalisis menggunakan teori Struktural Fungsional AGIL. Dari hasil penelitian yang dilakukan diketahui bahwa terdapat beberapa upaya mitigasi bencana banjir yang dilakukan masyarakat yaitu, (1). Mitigasi Fisik a). Merancang bangunan bebas banjir; b). Mengungsi tempat aman; c). Mengetahui jalur evakuasi; d). Memperbaiki saluran drainase. (2). Mitigasi Sosial a). Mencari informasi banjir; b). Tanda-tanda banjir; c). Kerjasama dalam mitigasi bencana; d). Menghadiri sosialisasi mitigasi bencana oleh Pemerintah.

Kata Kunci: mitigasi bencana, banjir, dadok Tunggul Hitam.

\section{Abstract}

The backgroud of this research is to determine flood disaster mitigation efforts in the community iDadok Tunggul Hitam, Koto Tangah, Padang city. This study used a qualitative approach to interviwing techiniques the resaarch observation were using structural fungsional theory from the results of this study flood mitigation carried out by the community, namely (1) physical mitigation, a). Designing flood free buildings; b). Evacuating safe places; c). Knowing evacuation routes; d). Repairing drainage channels. (2). Social mitigation, a). Seeking information on floods; b). Sings of flooding; c). Cooperation in disaster mitigation; d). Attending socialization of disaster mitigation by the government. Keywords: Disaster mitigation, floodin, dadok Tunggul Hitam
\end{abstract}

\section{Received: August 29, 2019 Revised: September 4, 2019 Published: September 5, 2019}


Bencana alam adalah kejadian yang tidak bisa dihadapi dan tidak tahu datangnnya bencana membuat masyarakat menjadi khawatir(Agus, 2005). Bencana alam yang terjadi membuat masyarakat menjadi gangguan jiwa serta membuat masyarakat menjadi kehilangan semangat seperti, tidak adanya semangat dalam hidupnya, rasa ketakutan yang menyerang dipikirannya (Nursingnal, 2018) salah satu bencana alam adalah bencana banjir. Banjir adalah terbenamnya daratan oleh genangan air yang diakibatkan dari adanya penyumbatan saluran air, jebolnya tanggul, tidak adanya daerah resapan air, serta curah hujan yang tinggi (Nurjihan, 2017). Banjir yang dirasakan masyarakat sangat memberikan pengaruh yang sangat tinggi terhadap masyarakat, sehingga masyarakat mendapatkan pengalaman yang dirasakan setiap tahunnya(Yulaelawati, 2008) Banjir yang terjadi memberikan dampak yang tidak baik kepada mayarakat sehingga masyarakat harus tanggap sebelum, selama dan setelah banjir terjadi (Priambodo, 2009)

Menurut Badan Penanggulangan Bencana Daerah (BPBD) wilayah Kota Padang memiliki delapan titik rawan bencana banjir yakni Simpang Kalumpang, By Pass Air Pacah di depan Terminal Regional Bingkuang (TRB), daerah Maransi Kelurahan Air Pacah, Rumah Potong Lubuk Buaya, dan daerah Ampang, Sungai Sapih Kecamatan Kuranji, Komplek Jondul Rawang Mata Air.

Mitigasi adalah suatu tindakan yang dilakukan untuk mengurangi resiko bencana sehingga bencana yang diakibatkan oleh perbuatan manusia dapat diminimalisirkan(Erianjoni, 2018) Mitigasi mempunyai tahapan terhadap bencana sebelum, selama dan setelah bencana(Aung, Rahman, Nurumal, \& Ahayalimudin, 2017)

Masyarakat yang mengalami kerugian serta keresahan setiap tahunya terhadap pengaruh lingkungan yang dirasakan masyarakat. Masyarakat tidak mempunyai pengetahuan upaya untuk mengurangi dampak dari bencana tersebut (Priambodo, 2009) Penelitian yang dilakukan di Dadok Tunggul Hitam masyarakat di sini melakukan bencana banjir yang dirasakan banjir setiap tahunnya dan juga masyarakat mempeunyai historis terhadap banjir yang dirasakan(As'ari \& Hendriawan, 2016)

Kelurahan Dadok Tunggul Hitam merupakan salah satu kawasan rawan bencana banjir. Pada kawasan ini, banjir yang terjadi disebabkan oleh kondisi saluran drainase yang kurang memadai dari luapan air parit yang mempunyai lebar \pm sekitar 2 meter dengan kedalaman 1,5 meter. Kawasan ini setiap tahunnya terkena banjir, baik itu banjir dalam skala besar maupun dalam skala kecil. Dari hasil wawancara dengan beberapa warga di Kelurahan Dadok Tunggul Hitam ditemukan bahwa banjir besar yang melanda kawasan ini sudah ada sejak tahun 1996, 2004, 2006, 2009, dan pada akhir tahun 2016. Berdasarkan informasi dari hasil wawancara Kepala Kelurahan Dadok Tunggul Hitam yang menyatakan bahwa banjir yang melanda kawasan ini memiliki ketinggian $\pm 1-1,5$ Meter, masyarakat merasa bahwa bencana banjir yang datang merupakan rutinitas setiap tahunnya. Selain banjir besar juga terjadi banjr-banjir kecil dengan ketinggian $\pm 0-50 \mathrm{~cm}$. Banjir ini terjadi pada saat musim hujan seperti bulan-bulan tertentu.

Sehingga masyarakat menganggap banjir adalah kebiasaan yang sudah lama dirasakan, mereka sudah memperkirakan berapa kedalaman ketika banjir terjadi, namun masyarakat tetap bertahan untuk tidak meninggalkan rumahnya. Sebelum terjadi bencana banjir maka ia lebih mendahulukan keselamatan yaitu isteri dan anaknya, saat terjadi banjir masyarakat terus mengantisipasi dengan membuat balok kayu untuk diletakkan di atas lantai dan meninggikan letak kasur, beserta barang-barang berharganya. Setelah peristiwa banjir ini, masyarakat banyak mengalami kerugian, seperti alat-alat elektronik yang konslet akibat terendam banjir yang berupa kulkas dan mesin cuci, alat-alat rumah tangga lainnya seperti lemari pakaian, lemari buku, lemari alat-alat masak, tempat tidur, kursi dan meja, ternak dan lainnya. Semua terbawa arus banjir sehingga masyarakat harus membeli kembali barang-barang yang dibutuhkan, jikapun barangbarang yang hanyut dan terendam banjir ditemukan, maka perlu diperbaiki kembali. Hal ini sudah menjadi kebiasaan masyarakat di sini yang sudah turun temurun tinggal di Kelurahan Dadok Tunggul Hitam.

\section{Culture \& Society: Journal of Anthropological Research Vol. 1, No. 1, Th. 2019}


Penelitian ini juga sejalan dengan penelitian sebelumnya Penelitian ini berbeda dengan penelitian sebelumnya. Penelitian yang dilakukan oleh Acmad Ridzki Ariyanda yakni faktor terjadinya banjir di Kelurahan Loa Bakung (Bakung \& Ariyanda, 2015) penelitian yang selanjutnya dilakukan Akhmad Asrofi yakni masyarakat Desa Bedono sebagai masyarakat pesisir melakukan berbagai macam strategi adaptasi dalam menghadapi bencana banjir rob (Kecamatan, Kabupaten, Jawa, Asrofi, \& Ritohardoyo, 2017) penelitan Dani Hendramawan menjelaskan Adaptasi Sosial Pengungsi Erupsi Gunung Merapi di Hunian Sementara (HUNTARA) Jenggala Dusun Plosokerep Desa Umbulharjo Kec. Cangkringan Kab. Sleman.(Dani Hedramawan, 2012)

Hasil observasi dan wawancara peneliti menemukan di Kelurahan Dadok Tunggul Hitam memiliki 64 RT, sedangkan jumlah RW di Kelurahan Dadok Tunggul Hitam ini berjumlah 15 RW. Alasan masyarakat tidak mau pindah dari kawasan ini adalah karena sudah terciptanya rasa nyaman dengan lingkungan sosial di sekitarnya. Adanya rasa solidaritas antar masyarakat yang sangat erat dan beberapa masyarakat sudah sejak lama tinggal di daerah ini. Mereka mempunyai historis masing-masing dirumah ini.

Sesuai dengan pernyataan Parsons yang mengemukakan bagian-bagian di dalam sistem saling berkaitan, dimana persepsi pemerintah dan masyarakat, bisa mempengaruhi kebertahanan masyarakat karena persepsi berkaitan dengan sistem dalam masyarakat sehingga sistem itu masih bisa bertahan. Jadi semua penyebab bertahan masyarakat akan berpengaruh pada keteraturan (order), keseimbangan (equilibirium) dan perubahan serta pengabaian konflik sebagai penekanan dari teori Talcott Parson mengenai Struktural Fungsional yang ada dalam masyarakat ini. Dengan adanya persepsi yang ada di tengah-tengah masyarakat ini menyebabkan masyarakat tetap mempertahankan dengan keadaan dan lingkungannya(Poloma, 1998)

\section{Metode Penelitian}

Mitigasi bencana banjir menjadi fokus dari penelitian ini. Penelitian dilakukan di Kelurahan Dadok Tunggul Hitam dengan menggunakan pendekatan kualitatif(Parsudi Suparlan, 1994) Pemilihan informan dengan teknik purposive sampling atau sampel bertujuan. Pemilihan informan dilakukan sesuai dengan kriteria yaitu (1) Badan Penanggulangan Bencana Daerah (BPBD), (2) Kelurahan Dadok Tunggul Hitam, (3) Warga dan Masyarakat Dadok Tunggul Hitam.

Pengumpulan data dalam penelitian ini menggunakan teknik wawancara, observasi dan dokumentasi. Wawancara adalah percakapan dengan maksud tertentu oleh dua pihak, yaitu pewawancara sebagai pengaju pertanyaan dan yang diwawancarai sebagai pemberi jawaban atas pertanyaan(Basrowi, 2008) Wawancara dilakukan secara mendalam namun dengan situasi non formal artinya peneliti bertanya seperti pembicaraan sehari-hari dengan menggunakan pedoman wawancara. Peneliti bertanya sesuai dengan pedoman wawancara dan pertanyaan disesuaikan dengan pedoman serta dikembangkan sesuai dengan keperluan tapi masih terkait dengan mitigasi bencana banjir yang dimaksud. Observasi yang dilakukan adalah peneliti terlibat langsung dalam kegiatan yang dilakukan oleh informan, serta kegiatan sehari-hari informan. Untuk memperkuat data yang diperoleh peneliti juga melakukan dokumentasi yang meliputi foto, rekaman dan video.

\section{Hasil dan Pembahasan}

\section{Mitigasi Bencana Banjir pada Masyarakat di Dadok Tunggul Hitam}

Penulis dalam hal ini menguraikan hasil temuan berdasarkan observasi dan wawancara langsung dilapangan. Berdasarkan hasil wawancara dengan beberapa narasumber, didapatkan meliputi:

\section{Mitigasi Fisik}

a. Merancang Bangunan Bebas Banjir

Penelitian penulis, yang dirasakan masyarakat banjir yang terjadi tidak bisa diterka-teka serta banjir yang dirasakan dengan ketinggian 2 meter. Air yang datang menggenangi permukiman 
penduduk. Sehingga masyarakat mempunyai pemikiran ingin merancang bangunana bebas banjir, merancang bangunan yang dilakukan masyarakat tidak membuat masyarakat untuk meyerah perubahan yang dilakukan demi untuk mengurangi terjadi dari ancaman bencana banjir yang dirasakan masyarakat.

Merancang bangunan bebas banjir masyarakat melakukan perubahan pada bentuk rumah yang menghasilkan fungsi baru, merancang bangunan rumah dari satu lantai sehingga menjadi dua lantai, untuk menjadikan lantai yang kedua sebagai ruang evakuasi bagi masyarakat di sini. Sehingga perubahan yang dilakukan tidak membuat masyarakat untuk bersedia meninggalkan kawasan tersebut. Namun semangat masyarakat untuk tinggal di kawasan ini agar terhindar dari bencana banjir yang sering terjadi banjir setiap tahunnya.

Sesuai dengan konsep AGIL yang dikemukakan oleh Parson, yaitu: Adaptasi yang dilakukan oleh masyarakat terhadap status dan peranan serta fungsi karena masing-masing sadar dengan status dan peranannya masing-masing. Dengan adanya tujuan-tujan yang hendak dicapai maka setiap anggota masyarakat harus menjalankan perannya, dengan adanya rasa solidaritas yang dimiliki juga dijadikan usaha untuk tetap mempertahankan. Penyesuaian dan kesepakatankesepakatan yang dilakukan gunanya adalah untuk pengintegrasian sebagai salah satu tujuan dari terbentuknya masyarakat. Dengan adanya rasa ikatan antara anggota masyarakat maka akan mudah memelihara pola dan nilai yang ada di dalamnya agar masyarakat tetap bertahan(Poloma, 1998).

\section{b. Mengungsi Tempat Aman}

Mengungsi yang dilakukan masyarakat untuk bisa lari demi bisa bertahan hidup yang dilakukan masyarakat dengan membawa keluraga mereka ke tempat yang baik. Dengan begitu masyarakat bisa melakukan dengan membawa keluraga mereka ke tempat kerabat mereka, sanak saudara yang memiliki tempat yang lebih tinggi dibandingkan rumahnya. Cara begitu masyarakat bisa menjalakan rutinitas yang dirasakan seperti biasanya(Kupucu Naim, 2008). Penelitian yang dilakukan becana banjir sebelum terjadi banjir masyarakat berusaha dengan cepat dan tanggap dalam meninggikan barang berharga ke tempat yang lebih tinggi sehingga saat terjadi banjir mereka sudah mengetahui langkah apa yang harus dilkukan untuk mengatasi bencana banjir dan setelah terjadi banjir masyarakat bisa memperbaiki apa yang sudah tidak bisa dipakai atau diperbaiki kembali (Baharuddin, 2018). Mengungsi guna menghindari suatu bencana atau musibah, masyarakat yang lari pada saat terjadi banjir memilih lari ke tempat keluarga mereka. Sebelumnya mereka belum pernah terjadi banjir di kawasan ini. Sehingga masyarakat di sini tidak mau mengungsi melainkan mereka dengan keluarganya tetap memantau situasi banjir yang terjadi dengan meyelamatkan harta benda mereka, berupa barang-barang berharga, surat-surat penting sudah mereka selamatkan dalam jauh-jauh hari. Baik itu dititipkan kepada saudara yang tinggal di kawasan aman bencana banjir, maupun di pegadaian. Sehingga mengungsi yang dilakukan masyarakat jika genangan banjir yang terjadi sudah melebihi orang dewasa, masyarakat membawa anak-anaknya ke tempat yang aman seperti masjid, sekolah dan rumah-rumah warga yang tempatnya aman untuk mengungsi. Berdasarkan hasil wawancara yang penulis peroleh di atas maka dapat disimpulkan bahwa masyarakat berusaha mempertahankan tempat tinggal mereka yang berada di daerah rawan bencana banjir, mereka mengungsi dengan tujuan untuk mencari tempat yang lebih aman untuk keselamatkan diri dan keluarga mereka dari ancaman bencana banjir, sehingga mengungsi yang dilakukan masyarakat jika genangan banjir yang terjadi sudah melebihi orang dewasa, masyarakat membawa anak-anaknya ke tempat yang aman seperti masjid, sekolah dan rumah-rumah warga yang tempatnya aman untuk mengungsi. Sesuai dengan konsep AGIL yang dikemukakan oleh Parson, yaitu: Adaptasi yang dilakukan oleh masyarakat terhadap status dan peranan serta fungsi karena masing-masing sadar dengan status dan peranannya masing-masing. Dengan adanya tujuan-tujan yang hendak dicapai maka setiap anggota masyarakat harus menjalankan perannya, dengan adanya rasa solidaritas yang dimiliki juga dijadikan usaha untuk tetap mempertahankan. Penyesuaian dan kesepakatan-kesepakatan yang dilakukan gunanya adalah untuk pengintegrasian sebagai salah satu tujuan dari terbentuknya 
masyarakat. Dengan adanya rasa ikatan antara anggota masyarakat maka akan mudah memelihara pola dan nilai yang ada di dalamnya agar masyarakat tetap bertahan(Poloma, 1998)

c. Mengetahui Jalur Evakuasi.

Jalur evakuasi yang dilakukan untuk dapat mengurangi bahaya yang dirasakan masyarakat, sehingga masyarakat bisa lebih cepat dan tuntas terhadap jalur yang diberikan oleh pemerintah. (Lindell and Whitney, 2000). Jalur evakuasi banjir di wilayah Kelurahan Dadok Tunggul Hitam, di prioritaskan di daerah rawan. Daerah yang rawan terjadinya banjir karena dataran yang rendah dibandingkan daerah sekitarnya. Kawasan Kelurahan Dadok Tunggul Hitam masih minim tanda jalur evakuasi. Berdasarkan informasi dilapangan, tempat evakuasi yang berhasil peneliti kumpulkan dari keterangan masyarakat menunjukan tempat evakuasi terdekat di Jalan DPR yang dijadikan opsi oleh warga untuk mengevakuasikan diri jika seandainya bencana banjir melanda Kelurahan Dadok Tunggul Hitam. Alasan mereka menganggap rumah tersebut memiliki pondasi yang sangat tinggi karena memiliki 2 lantai, sehingga ideal untuk tempat evakuasi banjir. Berdasarkan hasil temuan ada juga masyarakat yang membuat bangunan sendiri untuk evakuasi banjir, masyarakat semakin yakin memperkuat mental mereka untuk tetap bertahan di daerah rawan bencana banjir. Seperti pada gambar berikut ini:

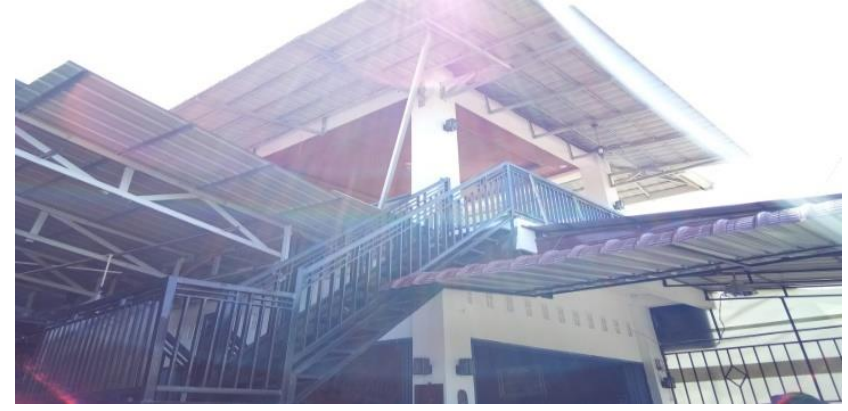

Gambar 1. Kondisi Rumah Pak Kudri

Berdasarkan observasi di atas masyarakat yang menjadikan rumah mereka sekaligus shellter membuat warga sekitar atau tetangga mereka yang tidak memiliki bangunan atau rumah yang bertingkat juga ikut mengevakuasikan. Sehingga warga dianjurkan untuk melakukan mitigasi bencana banjir untuk mengevakuasi diri ke rumah warga yang memiliki pondasi yang kokoh dan bertingkat.

Bahwa peneliti melihat masyarakat di sini mempunyai tujuan dalam menghadapi bencana banjir. Namun dalam pemikiran masyarakat, shelter yaitu bangunan yang mereka bangun untuk meninggikan barang-barang mereka serta dapat membawa masyarakat yang membutuhkan untuk menginap dan tinggal sementara di rumahnya.

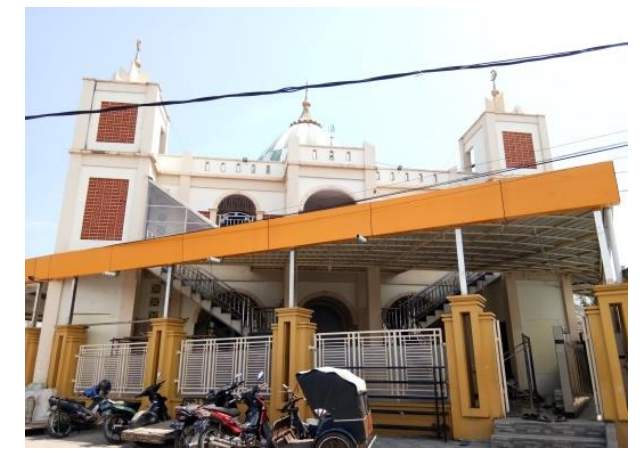

\section{Gambar 2. Masjid AL-Hijrah Dadok Tunggul Hitam}

Berdasarkan obeservasi tempat evakuasi banjir masyarakat Kelurahan Dadok Tunggul Hitam adalah memilih bangunan masjid bertingkat. Masyarakat merasa bahwa lari ke masjid bertingkat adalah tempat yang aman untuk menetap di masjid AL- Hijrah Kelurahan Dadok

\section{Culture \& Society: Journal of Anthropological Research Vol. 1, No. 1, Th. 2019}


Tunggul Hitam, bangunan yang masih berdiri kokoh dan bangunan yang tinggi. Berdasarkan hasil wawancara tersebut terlihat bahwa dari 30 informan terdapat 4 informan yang menyatakan masyarakat yang menetap di kawasan Kelurahan Dadok Tunggul Hitam memilih untuk menetap pada kawasan ini, namun jika sewaktu-waktu terjadi banjir dengan ketinggian \pm 1 meter mereka lebih memilih mengevakuasi ke tempat tetangga atau ke gedung-gedung yang bertingkat dan ke masjid tempat yang dekat dari rumah masyarakat.

Sesuai dengan konsep AGIL yang dikemukakan oleh Parson, yaitu: Adaptasi yang dilakukan oleh masyarakat terhadap status dan peranan serta fungsi karena masing-masing sadar dengan status dan peranannya masing-masing. Dengan adanya tujuan-tujan yang hendak dicapai maka setiap anggota masyarakat harus menjalankan perannya, dengan adanya rasa solidaritas yang dimiliki juga dijadikan usaha untuk tetap mempertahankan. Penyesuaian dan kesepakatankesepakatan yang dilakukan gunanya adalah untuk pengintegrasian sebagai salah satu tujuan dari terbentuknya masyarakat. Dengan adanya rasa ikatan antara anggota masyarakat maka akan mudah memelihara pola dan nilai yang ada di dalamnya agar masyarakat tetap bertahan(Poloma, 1998).

\section{d. Memperbaiki Saluran Drainase}

Memperbaiki saluran air yang disebabkan oleh perbuatan manusia, maka dari itu dilakukan rencana agar saluran air dapat diatasi sehingga masyarakat yang tinggal di sini bisa menjalankan tugas dan tanggung jawabnya demi kita bersama. Dengan tujuan kita bersama sehingga kita dapat memperbaiki saluran air yang ada sehingga air yang menggenagi rumah kita bisa mengalir dengan baik. Seperti pada gambar berikut ini:

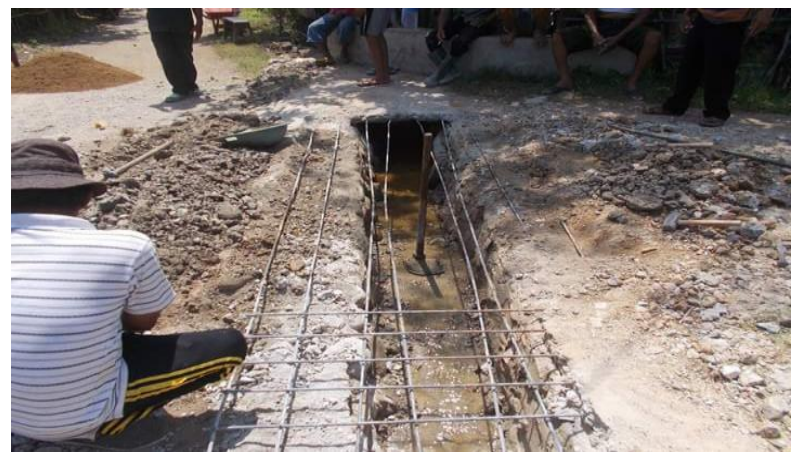

\section{Gambar 3. Memperbaiki Saluran Drainase Dadok Tunggul Hitam}

Berdasarkan hasil observasi tersebut terlihat bahwa dari 30 informan terdapat 5 informan yang menyatakan masyarakat yang mengatakan air mengalir memiliki setinggi \pm 1 mete. Dalam memperbaiki saluran air ini masyarakat harus lebih memiki rasa tanggung jawab bersama dalam mewujudkan saluran air menjadi lebih baik lagi, sehingga warga dan masyarakat mendapatkan keuntungan kita secara bersama dan bisa menjalakan dengan sebaik-baiknya. Upaya yang dilakukan masyarakat dalam mengatasi bencana dengan memiliki tahap-tahap sehingga masalah yang diupayakan untuk mengatasi bencana banjir bisa dilakukan.

Sesuai dengan konsep AGIL yang dikemukakan oleh Parson, yaitu: Adaptasi yang dilakukan oleh masyarakat terhadap status dan peranan serta fungsi karena masing-masing sadar dengan status dan peranannya masing-masing. Dengan adanya tujuan-tujan yang hendak dicapai maka setiap anggota masyarakat harus menjalankan perannya, dengan adanya rasa solidaritas yang dimiliki juga dijadikan usaha untuk tetap mempertahankan. Penyesuaian dan kesepakatankesepakatan yang dilakukan gunanya adalah untuk pengintegrasian sebagai salah satu tujuan dari terbentuknya masyarakat. Dengan adanya rasa ikatan antara anggota masyarakat maka akan mudah memelihara pola dan nilai yang ada di dalamnya agar masyarakat tetap bertahan(Poloma, 1998).

Culture \& Society: Journal of Anthropological Research Vol. 1, No. 1, Th. 2019 


\section{Mitigasi Sosial}

a. Mencari Informasi Banjir

Informasi disampaikan dengan segera kepada semua pihak, khususnya mereka yang terkena rawan bencana banjir. Masyarakat mengenai bencana banjir yang didapatkan informasi dari berbagai media. Seperti; Speaker, lisan, media sosial, televisi, radio, aplikasi chat dan ada yang telah mendapatkan sosialisasi dari pemerintah atau instansi terkait seperti PMI, BNPB, BPDB. Masyarakat menganggap bahwa Kelurahan Dadok Tunggul Hitam kawasan rawan bencana banjir, masyarakat mendapatkan informasi dilakukan upaya untuk mengatasi dan bisa memberikan informasi kepada masyarakat untuk mengurangi resiko terjadi bencana banjir.

Inisatif masyarakat melakukan perkumpulan tiap malam, sehingga masyarakat bisa saling bekerja sama dalam menjalankan tugas dan fungsinya. Peneliti melakukan observasi di Kelurahan Dadok Tunggul Hitam, seperti pada gambar berikut ini:

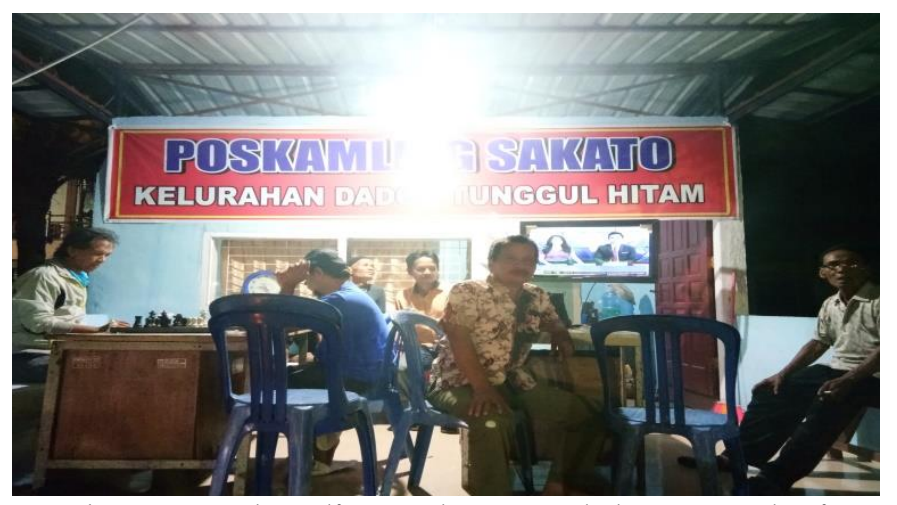

Gambar 5. Poskamling Sakato Dadok Tunggul Hitam

Masyarakat Kelurahan Dadok Tunggul Hitam, membuat Poskamling untuk melakukan warga supaya terlibat langsung dalam mengantisipasi kawasan rawan bencana banjir di sini, masyarakat dan tokoh pemuda membuat ronda malam supaya masyarakat di sini aktif dalam menjalankan tugas dan fungsinya ronda yang dilakukan secara bergiliran, dalam penjaga ronda diberikan rompi sebagai tanda penjaga di poskamling dan jika terjadi banjir, maka penjaga ronda memukul kentongan, dan membawa toa masjid dengan cara berteriak agar masyarakat mengetahui informasi banjir di Kelurahan Dadok Tunggul Hitam.Peneliti melakukan observasi seperti pada gambar berikut ini:
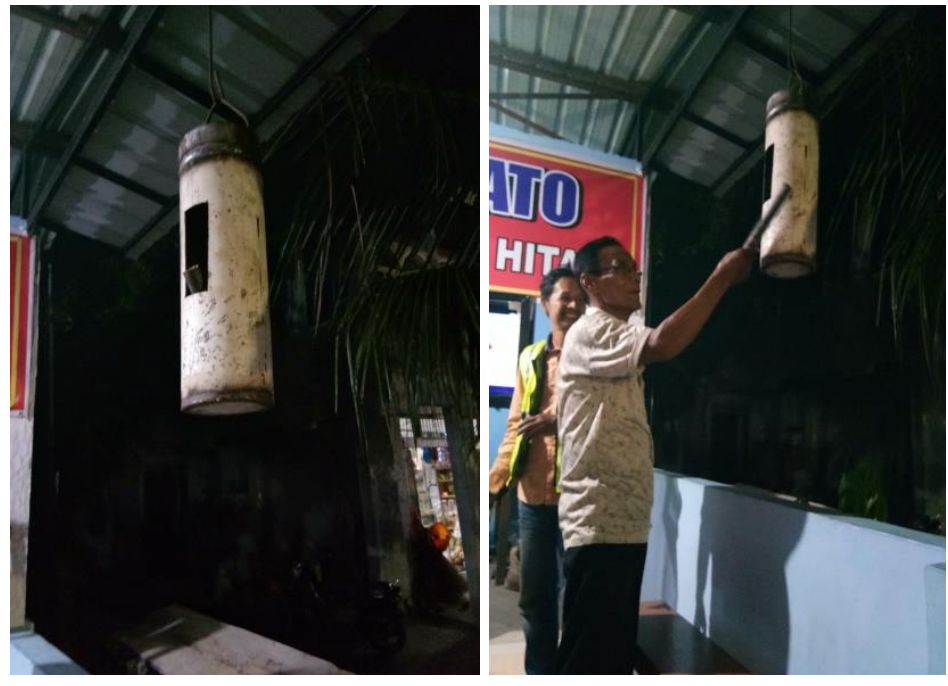

Gambar 6. Memukul Kentongan sambil meneriakkan Informasi banjir

Culture \& Society: Journal of Anthropological Research Vol. 1, No. 1, Th. 2019 
Berdasarkan hasil wawancara tersebut terlihat bahwa dari informan terdapat 6 informan yang menyatakan masyarakat mempunyai inisiatif sehingga bisa memberikan informasi kepada masyarakat. Cara inisiatif yang dilakukan warga dan masyarakat dengan memukul kentongan dan membawa Toa masjid untuk memberikan informasi kepada masyarakat agar dapat berjalan dengan baik demi keuntungan bersama.

Sesuai dengan konsep AGIL yang dikemukakan oleh Parson, yaitu: Adaptasi yang dilakukan oleh masyarakat terhadap status dan peranan serta fungsi karena masing-masing sadar dengan status dan peranannya masing-masing. Dengan adanya tujuan-tujan yang hendak dicapai maka setiap anggota masyarakat harus menjalankan perannya, dengan adanya rasa solidaritas yang dimiliki juga dijadikan usaha untuk tetap mempertahankan. Penyesuaian dan kesepakatankesepakatan yang dilakukan gunanya adalah untuk pengintegrasian sebagai salah satu tujuan dari terbentuknya masyarakat. Dengan adanya rasa ikatan antara anggota masyarakat maka akan mudah memelihara pola dan nilai yang ada di dalamnya agar masyarakat tetap bertahan(Poloma, 1998).

\section{b. Tanda-Tanda Banjir}

Masyarakat melihat tanda-tanda bencana banjir melalui intensitas curah hujan tinggi-sedang dengan begitu masyarakat bisa siap tanggap dalam mengurangi resiko bencana banjir, sehingga masyarakat mengetahui sebelum, saat dan setelah bencana banjir terjadi. Sesuai dengan konsep AGIL yaitu Adaptasi yang dilakukan oleh masyarakat demi bisa mempertahankan untuk menetap di kawasan rawan bencana banjir, karena masing-masing sadar dengan status dan peranannya. Dengan adanya tujuan-tujuan yang hendak dicapai yaitu masyarakat bisa bertahan di kawasan rawan bencana banjir maka setiap masyarakat harus menjalankannya dengan adanya Pengintegrasian masyarakat agar konflik yang terjadi dapat tercapai sebagai salah satu tujuan dari terbentuknya antar sesama masyarakat(Poloma, 1998)

\section{c. Kerjasama Dalam Mitigasi Bencana.}

Terbentuknya solidaritas dalam kehidupan masyarakat Kelurahan Dadok Tunggul Hitam adanya kekompakan dan keterikatan dari bagian-bagian yang ada. Dengan begitu, bahwa masyarakat telah menjalin kerjasama dan keterlibatan dalam memecahakan masalah menghadapi bencana banjir. Solidaritas masyarakat Kelurahan Dadok Tunggul Hitam sangat tinggi, artinya hubungan yang dijalin masyarakat saling menghargai orang lain dan merasakan kepuasan ketika membantu.

Menurut Parsons, di dalam masyarakat terdapat fungsi-fungsi yang saling berkaitan satu sama lainnya dan fungsi-fungsi tersebut tidak akan berjalan apabila ada salah satu fungsi yang tidak berjalan dengan baik. Dengan adanya rasa tolong menolong dengan instansi terkait yang dilakukan oleh BPBD dan sesama masyarakat juga maka fungsi-fungsi akan berjalan dengan baik. Begitu juga dengan ada sikap solidaritas, maka masyarakat harus menyesuiakan diri dengan keadaan tertentu. Rasa tolong menolong yang bisa menjadi alasan mengapa masyarakat tidak mau pindah dan tetap bertahan di dalam kawasan Kelurahan Dadok Tunggul Hitam.

\section{d. Menghadiri Sosialisasi Mitigasi Bencana oleh Pemerintah}

Sosialisasi mitigasi bencana dapat dilakukan dengan memberikan pengetahuan yang bersifat kognitif kepada masyarakat rawan bencana banjir. Dalam hal ini, masyarakat mempunyai peran yang cukup berarti bagi sosialisasi mitigasi bencana. Pada dasarnya telah cukup banyak peraturan yang mengatur berbagai hal yang menyangkut mitigasi bencana banjir pada masyarakat di Kelurahan Dadok Tunggul Hitam merupakan sebuah komitmen yang dilakukan masyarakat untuk mengurangi resiko bencana banjir untuk mewujudkan kesetaraan (persamaan) kesempatan dan partisipasi dalam berbagai aspek hidup dan penghidupan.

Sesuai dengan pernyataan Parsons yang mengemukakan bagian-bagian di dalam sistem saling berkaitan, dimana persepsi pemerintah dan masyarakat, bisa mempengaruhi kebertahanan 
masyarakat karena persepsi berkaitan dengan sistem dalam masyarakat sehingga sistem itu masih bisa bertahan. Jadi semua penyebab bertahan masyarakat akan berpengaruh pada keteraturan (order), keseimbangan (equilibirium) dan perubahan serta pengabaian konflik sebagai penekanan dari teori Talcott Parson mengenai Struktural Fungsional yang ada dalam masyarakat ini. Dengan adanya persepsi yang ada di tengah-tengah masyarakat ini menyebabkan masyarakat tetap mempertahankan dengan keadaan dan lingkungannya(Poloma, 1998)

\section{Kesimpulan}

Berdasarkan hasil penelitian penulis tentang Mitigasi Bencana Banjir Pada Masyarakat di Kelurahan Dadok Tunggul Hitam Kecamatan Koto Tangah Kota Padang. Dapat disimpulkan bahwa belum berjalan dengan maksimal, masih banyak permasalahan dan kendala yang dihadapi oleh masyarakat tersebut. Hal ini nantinya juga berpengaruh terhadap upaya-upaya mitigasi bencana banjir yang akan dilakukan oleh masyarakat. Masyarakat di Kelurahan Dadok Tunggul Hitam, menganggap mitigasi itu tidak penting, dan ada pula yang telah siap siaga dengan perlengkapan mitigasinya, mitigasi bencana banjir yang dilakukan masyarakat meliputi: (1). Mitigasi Fisik a). Merancang bangunan bebas banjir; b). Mengungsi tempat aman; c). Mengetahui jalur evakuasi; d). Memperbaiki saluran drainase. (2). Mitigasi Sosial a). Mencari informasi banjir; b). Tandatanda banjir; c). Kerjasama dalam mitigasi bencana; d). Menghadiri sosialisasi mitigasi bencana oleh Pemerintah.

\section{Daftar Pustaka}

Agus, D. (2005). Bencana Alam, Bencana Teknologi, Racun Dan Polusi Udara: Sebuah Tinjauan Psikologi Lingkungan. Buletin Psikologi, 13(1), 18-37. https://doi.org/10.22146/bpsi.13408

As'ari, R., \& Hendriawan, N. (2016). Kajian Nilai Kearifan Lokal Masyarakat Adat. 472-486.

Aung, K., Rahman, N. 'Inayatibt. A., Nurumal, M. S., \& Ahayalimudin, N. (2017). Ethical Disaster or Natural Disaster? Importance of Ethical Issue in Disaster Management. IOSR Journal of Nursing and Health Science, 06(02), 90-93. https://doi.org/10.9790/19590602079093

Baharuddin. (2018). A Phenomenological Study of Community Preparedness Experiencesin Facing the Flood Disaster in Napai Village of West Woyla Sub-District of West Aceh District. International Journal Of Medical Science And Clinical Invention, 5(3), 3610-3615. https://doi.org/10.18535/ijmsci/v5i3.10

Bakung, K. L. O. A., \& Ariyanda, A. R. (2015). Persepsi Masyarakat Tentang Penanggulangan Banjir Oleh Pemerintah Kota Samarinda (Studi Kasus Banjir DI. 3(4), 137-149.

Basrowi, \& S. (2008). Memahami Penelitian Kualitatif. Jakarta: Rineka Cipta.

Dani Hedramawan. (2012). Adaptasi Soisal Pengungsi Erupsi Gunung Di Hunian Sementara (HUNTARA) Jenggola Dusun Plososkerep Desa Umbulharjo Kec.Cangkringan Kab. Sleman.

Erianjoni, E. (2018). Pengembangan Materi Ajar Sosiologi Tentang Mitigasi Bencana Berbasis Kearifan Lokal Di Kota Padang. SOCIUS. https://doi.org/10.24036/scs.v4i2.24

Kecamatan, B., Kabupaten, S., Jawa, D., Asrofi, A., \& Ritohardoyo, S. (2017). Strategi Adaptasi Masyarakat Pesisir Dalam Penanganan Bencana Banjir Rob Dan Implikasinya Terhadap Ketahanan Wilayah ( Studi Di Desa. 23(2), 125-144.

Kupucu Naim. (2008). Cluture of Preparedness. Jurnal. Retrieved from Of Disaster Prevention and Management 17.(4), 1-7

Lindell M.K and Whitney. (2000). Correlates of Household Seismic Hazard Adjusment Adaptation. Retrieved from Risk Analysis, 20(1)

Nurjihan, H. (2017). Adaptasi Sosial Masyarakat Kawasan Banjir di Desa Bojongloa Kecamatan Rancakek. Pemikiran Dan Penelitian Sosiologi.

Nursingnal. (2018). Kesiapsiagaan Taruna Dalam Menghadapi Bencana Tsunami Di Balai Pendidikan Dan Pelatihan. Idea Nursing Journal, 9(1).

\section{Culture \& Society: Journal of Anthropological Research Vol. 1, No. 1, Th. 2019}


Parsudi Suparlan. (1994). Metode Penelitian Kualitatif. Jakarta: Universitas Indonesia.

Poloma, M. (1998). Sosiologi Kontemporer. Jakarta: Rineka Cipta.

Priambodo, S. A. (2009). Panduan Praktis Menghadapi Bencana : Badai, Banjir, Gempa Bumi, Letusan Gurung Api, Kerusuhan Massal, Teror Bom, Kebakaran, Polusi Lingkungan. 110.

Yulaelawati, U. (2008). Mencerdasi Bencana. Jakarta: Gramedia Widiasarana Indonesia. 